\title{
Cephalometric Evaluation of Children with Allergic Rhinitis and Mouth Breathing
}

\author{
Avaliação Cefalométrica em Crianças com Rinite Alérgica e Respiração Oral
}

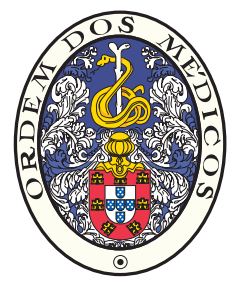

Helena Afonso AGOSTINHO $\rrbracket^{1,2}$, Ivo Álvares FURTADO ${ }^{1,2,3}$, Francisco Salvado e SILVA ${ }^{1,2}$, Josep USTRELL TORRENT ${ }^{4}$ Acta Med Port 2015 May-Jun;28(3):316-321

\section{ABSTRACT}

Introduction: Orthodontists frequently treat children with mouth breathing. The purpose of the present study was to examine dental positions, skeletal effects and the pharyngeal airway space of children with chronic allergic rhinitis, when compared with a control group exhibiting a normal breathing pattern.

Material and Methods: Seventy Caucasian children from Santa Maria University Hospital - North Lisbon Hospital Center were evaluated, between September 2009 and February 2013. The study group comprised of 35 children with chronic allergic rhinitis, both genders, aged 5 - 14, with positive reaction to allergens, mouth breathing and malocclusion. The control group was composed of 35 children, both genders, displaying normal nasal breathing and malocclusion, who resorted to the orthodontic department. Measures of Ricketts, Steiner and McNamara's analysis were used and the t- Student test was applied to the data obtained.

Results: Statistically significant differences were observed between the oral and nasal breathers, respectively: lower facial height $(49.1 / 45.9 \mathrm{~mm})$, Frankfurt - mandibular plane angle $\left(30.1 / 26.9^{\circ}\right)$ and Sela-Nasion - oclusal plane angle $\left(17.3 / 15^{\circ}\right)$, maxillary length $(78.4 / 82.4 \mathrm{~mm})$, mandibular length $(102.4 / 107 \mathrm{~mm})$, overbite $(0.8 / 3.1 \mathrm{~mm})$ and overjet $(4 / 4.7 \mathrm{~mm})$.

Discussion: Comparison between the allergic rhinitis and control group showed that there is an increased lower facial height, larger Frankfurt - mandibular plane angle and Sela-Nasion oclusal plane angle in children with chronic allergic rhinitis. This group also had a shorter maxillary and mandibular length, less overbite and decreased upper airway space.

Conclusions: Children with allergic rhinitis and mouth breathing have longer faces, shorter maxillas and mandibles and a narrowed pharyngeal airway space. No statistical differences between the groups in sagital relationships or in dental inclinations were found.

Keywords: Allergic, Perennial; Cephalometry; Child; Mouth Breathing; Portugal; Rhinitis.

\section{RESUMO}

Introdução: Os ortodontistas tratam frequentemente crianças com respiração oral. O objectivo deste estudo foi avaliar as posições dentárias, efeitos esqueléticos e espaço aéreo da faringe, causados pela respiração bucal em crianças com rinite alérgica crónica, comparando com grupo de controlo de padrão respiratório normal.

Material e Métodos: Foram avaliadas setenta crianças caucasianas do Hospital Universitário de Santa Maria (Lisboa), entre Setembro/2009 e Fevereiro/2013. O grupo de estudo compreendia 35 crianças com rinite alérgica crónica de ambos os géneros, idades entre 5 e 14 anos, reação positiva a aeroalergénios, respiração bucal e má-oclusão dentária. O grupo controlo incluiu 35 crianças, da mesma idade, ambos os géneros, com respiração nasal e má-oclusão dentária, que recorreram ao departamento de ortodontia. Utilizaram-se medidas de Ricketts, Steiner e análise de McNamara. Foi aplicado teste estatístico t de Student.

Resultados: Verificaram-se diferenças estatísticas significativas entre respiradores orais e nasais, respectivamente quanto à altura facial inferior $(49,1 / 45,9 \mathrm{~mm})$, ângulo entre o plano de Frankfurt e o plano mandibular $\left(30,1 / 26,9^{\circ}\right)$, ângulo entre a linha Sela-Nasion e o plano oclusal $\left(17,3 / 15^{\circ}\right)$, comprimento maxilar $(78,4 / 82,4 \mathrm{~mm})$ e mandibular $(102,4 / 107 \mathrm{~mm})$, overbite $(0,8 / 3,1 \mathrm{~mm})$ e overjet $(4 / 4,7$ $\mathrm{mm})$.

Discussão: A comparação entre os grupos demonstrou que as crianças com rinite alérgica e respiração oral apresentam maior altura facial inferior, maior ângulo entre o plano de Frankfurt e o plano mandibular e maior ângulo entre a linha Sela-Nasion e o plano oclusal. Este grupo apresentou também menor comprimento da maxila e da mandíbula, menor overbite e diminuição do espaço aéreo respiratório superior.

Conclusões: As crianças com rinite alérgica e respiração oral têm faces mais longas, maxilas e mandíbulas mais curtas e espaço aéreo faríngeo menor. Não existem diferenças estatísticas significativas entre grupos nas bases ósseas (plano sagital) ou inclinações dentárias.

Palavras-chave: Cefalometria; Criança; Portugal; Respiração Oral, Rinite Alérgica.

\section{INTRODUCTION}

Allergic rhinitis is the most frequent chronic pathology affecting children. ${ }^{1}$ It is rarely observed as an isolated pathology, often being associated with asthma, ${ }^{2-5}$ sinusitis, lymphoid tissue hypertrophy and obstructive sleep apnea. ${ }^{2-3}$ There is a prevalence of 75 to $80 \%$ of asthma in patients who

have allergic rhinitis. ${ }^{5}$ Many of these patients also display mouth breathing. Rhinitis prevalence increases with age, ${ }^{4,6}$ presenting wide variable values between countries and studies. For example, in the United Kingdom, asthma has a prevalence of $20 \%$ and allergic rhinitis has a prevalence

\footnotetext{
1. Pediatric Stomatology Unit. Department of Stomatology. Hospital de Santa Maria. Centro Hospitalar Lisboa Norte. Lisbon. Portugal.

2. Instituto de Saúde Ambiental. Faculdade de Medicina. Universidade de Lisboa. Lisbon. Portugal.

3. Instituto de Anatomia. Faculdade de Medicina. Universidade de Lisboa. Lisbon. Portugal.

4. Department of Stomatology. Faculty of Odontology. Universidad de Barcelona. Barcelona. Spain.

$\triangle$ Autor correspondente: Helena Afonso Agostinho. helenagostinho.master@gmail.com

Recebido: 31 de Outubro de 2014 - Aceite: 15 de Fevereiro de 2015 | Copyright @ Ordem dos Médicos 2015
} 
of $40 \%$ at the age of $13-14$. In Spain, the prevalence of allergic rhinitis is $30.4 \%$ at the age at which children start school and $47.3 \%$ at the age of $13-14 .^{7,8}$

In Portugal, the prevalence of rhinitis is $21.5 \%$ among 3 to 5 year-olds. ${ }^{9}$ Among patients with malocclusion, $48.3 \%$ have a pathology of the rhino-pharynx, $40 \%$ have allergic rhinitis and $16.5 \%$ suffer from tonsil hyperthrophy. ${ }^{10}$

According to Moss ${ }^{11}$ functional matrix theory, the craniofacial structures' growth is influenced by the soft tissues. Soft tissues morphology, position and breathing will condition the craniofacial morphology. However the relationship between nasal obstruction and craniofacial growth is not evident. ${ }^{12}$ In a review study, McNamara ${ }^{13}$ refers that Meyer (1872), Angle (1907) and Rickets (1968), among others, related nasal obstruction with complex craniofacial growth functional deviations called 'adenoid face', a conditioned characterized by mouth breathing, small nose, thin upper lip and narrow maxilla. In a study conducted on monkeys whose nasal cavities had been obstructed, it was observed that the primates consequently developed mouth breathing, with increased growth of facial and tongue muscles. ${ }^{14,15}$ These studies also reported changes in mandible morphology, in spite of some divergences: in some monkeys, the posterior and inferior rotation of the mandible occurred with consequent Class II occlusion and in other monkeys it was possible to observe anterior rotation and Class III malocclusion.

Although some authors, such as Harvold et al, ${ }^{15}$ claim that there are no postural differences in the head and neck between nose and mouth breathers, the general consensus is that there are noticeable postural changes in mouth breathers. ${ }^{16-21}$ Patients who display mouth breathing show a greater head extension, with an anterior projection towards

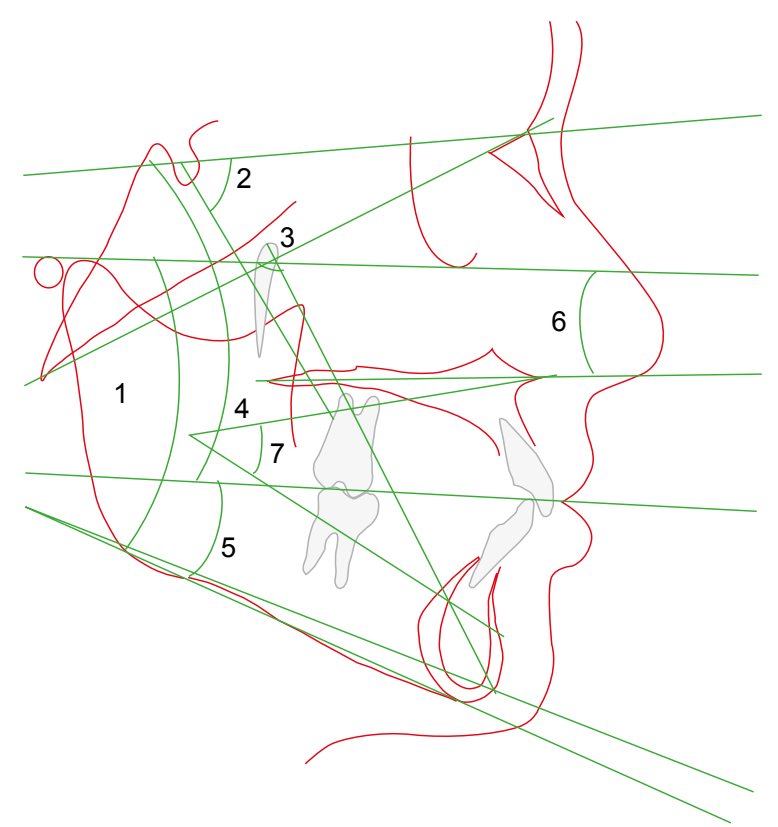

Figure 1 - Vertical skeletal cephalometric variables: 1, FMA; 2, SN.Gn; 3, Ricketts axis; 4, SN.Opl; 5, Opl.GoGn; 6, Ricketts palatal angle; 7 , IFH (inferior face height). the cervical column, and a higher degree of lordosis. ${ }^{22}$ Patients with vertical patterns ${ }^{23}$ have a similar lung volume but quantitatively less nasal breathing than 'mesofacials'. Mouth breathers presents: bigger facial height, ${ }^{24-26}$ higher frequency of maxillary retrognathism, ${ }^{25-27}$ deeper palate, ${ }^{26,28,29}$ maxillary retrognathism, ${ }^{25}$ anterior open-bite and Class II malocclusion, ${ }^{27,30}$ posterior crossed bite, ${ }^{29,30}$ normal upper inter-molar and inter-canine distance, ${ }^{28}$ decreased perimeter of superior and inferior arch, ${ }^{29,31}$ vestibular tilting of the upper incisors, ${ }^{21}$ retro-inclination of inferior incisors, ${ }^{21,26}$ and greater dental crowding. ${ }^{31}$

Based on the facts stated previously, the aim of this study was to analyze the facial pattern of both mouth and nasal breathers in order to determine if there are significant vertical or sagittal alterations of the bone structure between both groups and understand if there are alterations in dental tilting. Finally, the width of the upper and lower pharyngeal airway was also compared between both groups.

\section{MATERIAL AND METHODS}

Seventy Caucasian children from Santa Maria University Hospital - North Lisbon Hospital Center were divided in two groups - the Allergic group (G1) and the Control Group (G2) and were evaluated between September 2009 and February 2013. The study was approved by the Ethics Committee of the Hospital. Children that were submitted to previous tonsil and adenoid surgery, that had finger or dummy suction habits beyond three years of age, or that presented any genetic syndromes, were automatically excluded from the study. The Allergic group (G1) consisted of 35 children (24 boys and 11 girls), with an average age of 10 years and 2 months old, chronic allergic rhinitis confirmed by positive tests to specific breathing allergens, mouth breathing

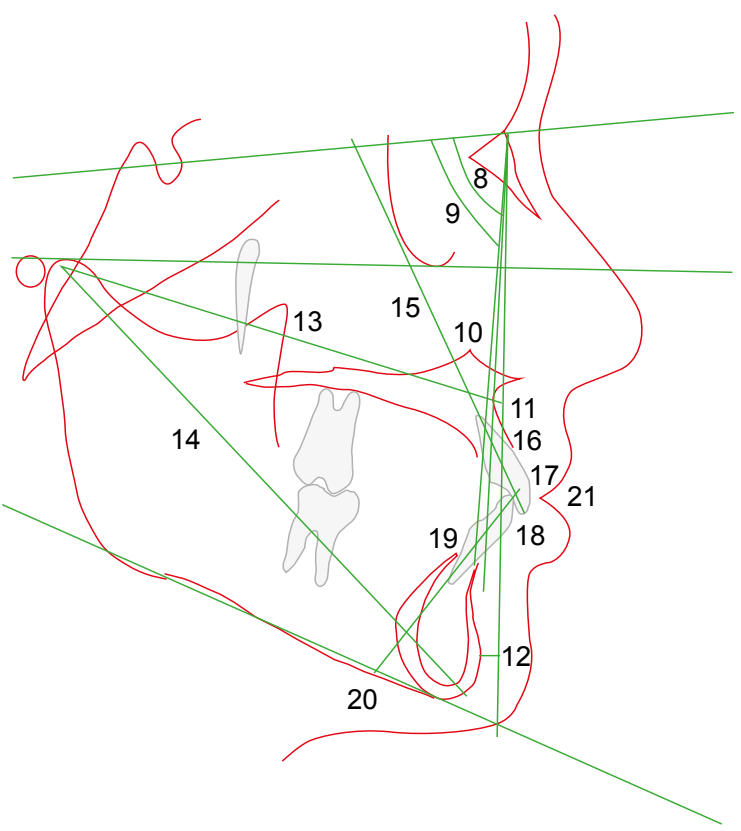

Figure 2 - Sagital skeletal and dental cephalometric variables: 8, SNA; 9, SNB; 10, ANB; 11, A-Nperp; 12, Pg-Nperp; 13, Co-A; 14, Co-Gn; 15, 1.SN; 16, 1.NA; 17; 1-NA; 18; 1-NB; 19, 1.NB; 20 , IMPA; 21, 1.1. 
confirmed by a standard questionnaire and by an additional confirmatory test, in which each child was asked to breathe through their nose. Those who were able to breathe through their nose for more than one minute were excluded from the group, even if the questionnaire indicated that they might have oral breath. Additionally, the children all had some kind of malocclusion that required orthodontic treatment, since it was not possible to submit them to a teleradiography, by the ethic committee standards. The control group (G2) consisted of 35 children (17 boys and 18 girls), with an average age median age of 11 years and 5 months, that went to an orthodontic appointment at the same hospital. The inclusion criteria were: normal nasal breathing, absence of an allergic pathology or otorhinolaryngology diseases and presence of malocclusion. Children were submitted to an orthodontic study, based on a digital profile teleradiography, taken in the Hospital's Radiology department, always using the same X-Ray digital machine.

\section{Cephalometric measurements}

The measures of Rickets, Steiner and McNamara were taken (Fig.s 1 and 2). We choose parameters that did not change with age (Table 1). The airway space analysis was conducted by calculating the distances between the anterior and posterior pharyngeal walls, at five different vertical points (Fig. 3).

The measurements were all performed by the same professional (HAA), using the Nemoceph Studio software. Twenty radiographs of the children were compared and no system errors were found. The statistical analysis was performed with SPSS, (version 17), and the Student t-test was used for the groups comparison. In all of the statistical analysis, a significance value of 0.05 was considered.

\section{RESULTS}

The skeletal, dental and soft tissues relationships, as well as airway space are described in Tables 2 and 3.

A statistically significant Frankfurt - mandibular plane angle (FMA) difference $(p=0.006)$ between the two groups was observed, with the allergic individuals being more vertical. Also statistically significant differences were found at the Sela-Nasion line and oclusal plane angle (SN.OPL) and Ricketts anterior-inferior skeletal height (IFH) level with a $p$-value of $p=0.02$ and $p=0.001$, respectively. The most significant difference was an increase of the inferior facial height. It was also observed that, in general, G1 presented smaller maxillas, measured between Condilium and A point $(\mathrm{Co}-\mathrm{A})(p=0.006)$ and in mesurement between condilium

Table 1 - Measurements

\begin{tabular}{|c|c|}
\hline FMA $\left({ }^{\circ}\right)$ & Frankfurt plane (Po-Or) and mandibular plane (Go-Me) angle. \\
\hline SN.Gn $\left({ }^{\circ}\right)$ & Angle between Nasion, Sella and Gnation point. \\
\hline Facial axis $\left({ }^{\circ}\right)$ "Rickets" & Posterior angle between Basion-Nasion line and Pterigomaxilar-Gnation line. \\
\hline SN.Opl $\left({ }^{\circ}\right)$ & Sella-Nasion line and oclusal plane angle. \\
\hline Opl.GoGn $\left({ }^{\circ}\right)$ & Angle between oclusal plane and Gonion-Gnation plane. \\
\hline Ricketts Palatal angle & Frankfurt plane (Po-Or) and palatal plane (ANS-PNS) angle. \\
\hline $\mathrm{IFH}\left({ }^{\circ}\right)$ & Angle between ANS-Xi line and Xi-Pm plane. \\
\hline $\operatorname{SNA}\left({ }^{\circ}\right)$ & Sella-Nasion-A point angle. \\
\hline $\operatorname{SNB}\left({ }^{\circ}\right)$ & Sella-Nasion-B point angle. \\
\hline ANB $\left({ }^{\circ}\right)$ & A point-Nasion-B point angle. \\
\hline A - Nperp (mm) & Distance between A point and Nasion perpendicular line. \\
\hline Pg - Nperp (mm) & Distance between Pg point and Nasion perpendicular line. \\
\hline Co - A (mm) & Maxillar length. \\
\hline Co - Gn (mm) & Mandibular length. \\
\hline 1. $\mathrm{SN}\left({ }^{\circ}\right)$ & Upper incisor angle to SN line. \\
\hline 1. $N A\left({ }^{\circ}\right)$ & Upper incisor angle to NA line. \\
\hline $1-\mathrm{NA}(\mathrm{mm})$ & Upper incisor distance to NA line. \\
\hline $1-\mathrm{NB}(\mathrm{mm})$ & Lower incisor distance to NB line. \\
\hline 1. NB $\left({ }^{\circ}\right)$ & Lower incisor angle to NB line. \\
\hline $\operatorname{IMPA}\left({ }^{\circ}\right)$ & Lower incisor mandibular plane angle. \\
\hline 1. $1\left(^{\circ}\right)$ & Interincisal angle. \\
\hline Overjet $(\mathrm{mm})$ & Horizontal distance between incisors edges. \\
\hline Overbite (mm) & Vertical distance between incisors edges. \\
\hline
\end{tabular}




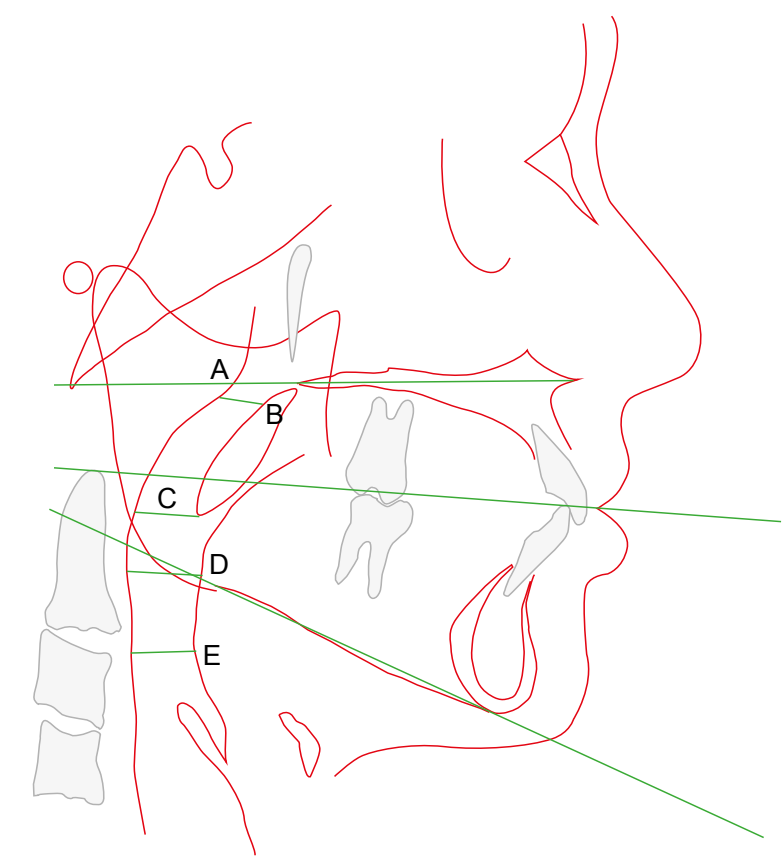

Figure 3 - Pharyngeal airway space variables: A, distance between PNS and posterior wall of pharynx in ANS-PNS plane; B, superior McNamara airway space taken on half superior of soft palate (Npa$\mathrm{Npp}$ ) and measured on the narrowed space between soft palate and posterior wall of pharynx; $\mathrm{C}$, distance between inferior soft palate point $(\mathrm{Ppm})$ and posterior wall of pharynx in a line parallel to oclusal plane; D, inferior McNamara airway space (Bfa-Bfp) measured from intersection of posterior border of tongue and inferior border of mandible to the closer point on posterior pharyngeal wall; $\mathrm{E}$, hipopharyngeal airway space, the narrowed space found from anterior to posterior wall of pharynx below the mandible border.

and Gnation (Co-Gn) ( $p=0.03)$.

There were no statistically significant alterations of the sagittal relationships between groups, although the $\mathrm{G} 1$ has a higher ANB value than G2.

There were no statistically relevant changes of the relationship between the incisors inclinations and skull base. For each arcade, two angular measurements (1.SN, 1.NA, 1.NB, IMPA) and one linear measurement (1-NA, 1-NB) were performed.

There was, however, a statistically significant alteration for overbite: children in the study group had a higher open bite tendency.

In the airway space, a statistically significant decrease in the distance between posterior nasal spine and posterior wall of pharynx distance (Pns-Pp1 with $p=0.028$ ); decrease in superior McNamara airway space, taken on half superior of soft palate and measured on the narrowed space between soft palate and posterior wall of pharynx (NpaNpp with $p=0.013)$; decrease distance between inferior soft palate point (Ppm) and posterior wall of pharynx in a line parallel to oclusal plane (Ppm-Pp2 with $p=0.02)$ and decrease inferior McNamara airway space measured from intersection of posterior border of tongue and inferior border of mandible to the closest point on posterior pharyngeal wall (Hpa-Pp3 with $p=0.036$ ) was observed.

\section{DISCUSSION}

For ethical reasons (unnecessary radiation exposure), it was not possible to study and directly compare every children with mouth or nasal breathing - only children with malocclusion, who were in need of orthodontic treatment, were subjected to the teleradiography. Therefore, this study focused instead on comparing pure cephalometric alterations in children with malocclusion who presented different patterns of breathing. Another major limitation in the sample gathering was the fact that many children with allergy problems had had a history of either tonsil or adenoid pathology and had already undergone surgery, excluding them from the study.

More often than not, children with skeletal Class II are referred as mouth breathers but some studies did not clarify if it this was caused by the vestibular tilting of the upper incisors (that consequently do not allow the lips to seal and could possibly end up leading to mouth breathing) or not. ${ }^{39,40}$ Although not statistically significant to our study, an increased A point-Nasion-B point (ANB) angle was observed in G1 group. In many mouth breathing studies, it has been observed that mouth breathers have an increased tilting of the upper incisors and retroposition of the lower incisors. However, we did not observe that in the present study. This could potentially be explained by our decision to reject every child with suction habits beyond the age of 3 . If those children were included in the said studies, that could have led to different results.

Our decision to exclude those children is explained by our desire to analyze nothing but their way of breathing. Children that displayed mouth breathing were skeletally more vertical in accordance with previous studies, ${ }^{24,26,32,41}$ suggesting that a narrower airway space may lead to a more accentuated vertical growth. This growth, along with posterior rotation of the mandible, secondary leads to a reduction of the overbite, on these children. This difference was also shown to be statistically significant in previous studies. $^{14,21}$

As in our study, in another previous study, ${ }^{28}$ it has also been observed that they have shorter maxillary and mandibular lengths. The pharynx was evaluated at five different vertical points, with the purpose of evaluating if there were any specific areas of bigger or smaller dimension. A statistically significant difference in the BfaBfp measurements has not been found, as demonstrated in some studies, ${ }^{34,35}$ showing that there was no relation between vertical growth and airway space in that area.

We can speculate that this measurement has not changed, in disagreement with other studies' results (that seem to have observed an increase of this value), due to a more forward position of the tongue in the mouth breathers.

A statistically significant difference in the PNS-Pp1 and Npa-Npp (Fig. 3, measurements A and B) was observed, showing a narrower nasopharynx in the mouth breathers group, in accordance with previous studies. ${ }^{36-38,41}$ The distance between Ppm-Pp2 was also found to be smaller, showing that there was a reduced space between the 


\begin{tabular}{|c|c|c|c|c|c|}
\hline & \multicolumn{2}{|c|}{$\begin{array}{c}\text { G1 } \\
\text { (Mouth breathers) }\end{array}$} & \multicolumn{2}{|c|}{$\begin{array}{c}\text { G2 } \\
\text { (Nose breathers) }\end{array}$} & \multirow[b]{2}{*}{$\boldsymbol{P}^{*}$} \\
\hline & Mean & SD & Mean & SD & \\
\hline $\operatorname{FMA}\left({ }^{\circ}\right)$ & 30.1 & 5.3 & 26.9 & 4.2 & 0.006 \\
\hline SN-Gn $\left({ }^{\circ}\right)$ & 68.5 & 4.0 & 67.9 & 3.3 & ns \\
\hline Ricketts facial axis $\left({ }^{\circ}\right)$ & 88.5 & 4.1 & 89.6 & 3.9 & ns \\
\hline SN.Opl $\left({ }^{\circ}\right)$ & 17.3 & 4.5 & 15.0 & 3.7 & 0.02 \\
\hline Opl.GoGn $\left({ }^{\circ}\right)$ & 18.6 & 4.4 & 17.5 & 2.9 & ns \\
\hline Ricketts palatal angle & -1.6 & 3.2 & -0.7 & 3.0 & ns \\
\hline $\mathrm{IFH}\left({ }^{\circ}\right)$ & 49.1 & 3.9 & 45.9 & 4.1 & $0.001^{* *}$ \\
\hline $\operatorname{SNA}\left({ }^{\circ}\right)$ & 81.8 & 4.2 & 81.7 & 3.4 & ns \\
\hline $\operatorname{SNB}\left({ }^{\circ}\right)$ & 77.4 & 3.8 & 78.0 & 3.4 & ns \\
\hline ANB $\left({ }^{\circ}\right)$ & 4.4 & 2.9 & 3.7 & 3.0 & ns \\
\hline A - Nperp (mm) & -0.5 & 3.6 & -0.5 & 3.3 & ns \\
\hline Pg - Nperp (mm) & -8.0 & 6.3 & -6.9 & 6.1 & ns \\
\hline Co - A (mm) & 78.4 & 6.1 & 82.4 & 5.6 & $0.006^{* *}$ \\
\hline Co - Gn (mm) & 102.4 & 9.2 & 107.0 & 8.0 & $0.03^{*}$ \\
\hline 1. $\mathrm{SN}\left({ }^{\circ}\right)$ & 107.4 & 7.3 & 105.5 & 7.9 & ns \\
\hline 1. $\mathrm{NA}\left({ }^{\circ}\right)$ & 25.5 & 6.5 & 23.8 & 8.4 & ns \\
\hline 1 - NA (mm) & 4.8 & 3.6 & 4.9 & 3.6 & ns \\
\hline $1-\mathrm{NB}(\mathrm{mm})$ & 6.3 & 2.6 & 5.4 & 2.0 & ns \\
\hline 1. NB $\left({ }^{\circ}\right)$ & 28.4 & 6.6 & 27.2 & 4.4 & ns \\
\hline $\operatorname{IMPA}\left({ }^{\circ}\right)$ & 92.9 & 7.4 & 94.4 & 5.5 & ns \\
\hline 1. $1\left(^{\circ}\right)$ & 121.7 & 11.9 & 125.2 & 9.7 & ns \\
\hline Overjet (mm) & 4.0 & 2.9 & 4.7 & 2.0 & ns \\
\hline Overbite (mm) & 0.8 & 2.6 & 3.1 & 1.7 & $0.000^{* *}$ \\
\hline
\end{tabular}

Table 3 - Means and standard deviations of the pharyngeal airway measures ( $t$-test)

\begin{tabular}{|c|c|c|c|c|c|}
\hline & \multicolumn{2}{|c|}{$\begin{array}{c}\text { G1 } \\
\text { (Mouth breathers) }\end{array}$} & \multicolumn{2}{|c|}{$\begin{array}{c}\text { G2 } \\
\text { (Nose breathers) }\end{array}$} & \multirow[b]{2}{*}{$P$} \\
\hline & Mean & $S D$ & Mean & $\mathrm{SD}$ & \\
\hline A & 21.4 & 4.5 & 23.9 & 4.9 & $0.028^{*}$ \\
\hline B & 8.8 & 3.3 & 11.0 & 4.0 & $0.013^{*}$ \\
\hline C & 9.4 & 2.9 & 11.0 & 2.6 & $0.020^{*}$ \\
\hline D & 11.2 & 3.0 & 12.4 & 3.5 & ns \\
\hline E & 8.7 & 3.1 & 10.4 & 3.5 & $0.036^{*}$ \\
\hline
\end{tabular}

anterior and posterior wall, as well as in the inferior portion of the pharynx, where a narrower space was found between the anterior and posterior part, at the C3 level.

\section{CONCLUSIONS}

This study showed that:

1) Children with allergic rhinitis and mouth breathing are skeletally more vertical, with an open bite tendency;

2) These children have a smaller maxilla and mandible when compared to the nasal breathing children;
3) There are no sagital base alterations although there is an increased tendency for a skeletal Class II;

4) There is a reduced airway space in all of its extension, except between the posterior wall of the tongue and the posterior pharyngeal wall, probably due to an anterior position of the tongue in children that may present obstruction.

\section{PROTECTION OF HUMANS AND ANIMALS}

The authors declare that the study was approved by the Ethics Committee of the Hospital and that the described procedures followed the regulations established by the Clinical Research and Ethics Committee and to the Helsinki Declaration of the World Medical Association.

\section{DATA CONFIDENTIALITY}

The authors declare that they followed the protocols in use at their working center regarding patient's data publication.

\section{CONFLICTS OF INTEREST}

The authors declare that there are no conflicts of interest.

\section{FUNDING SOURCES}

No subsidies or grants contributed to this work. 


\section{REFERENCES}

1. Newacheck PW, Stoddard JJ. Prevalence and impact of multiple childhood chronic illness. J Pediatr. 1994;124:40-8.

2. Sacre Hazouri JA. Allergic rhinitis. Coexistent diseases and complications. A review and analysis. Rev Alerg Mex. 2006;53:9-29.

3. Chung F, Barnes N, Allen M, Angus R, Corris P, Knox A, et al. Assessing the burden of respiratory disease in UK. Resp Med. 2002;96:963-75.

4. Kang HY, Kang HY, Park CS, Bang HR, Sazonov V, Kim CJ. Effect of allergic rhinitis on the use and cost of health services by children with asthma. Yonsei Med J. 2008;49:521-9.

5. Lasmar LM, Camargos PA, Ordones AB, Gaspar GR, Campos EG, Ribeiro GA. Prevalence of allergic rhinitis and its impact on the use of emergency care services in a group of children and adolescents with moderate to severe persistent asthma. J Pediatr. 2007;83:555-61.

6. Tornador-Gaya E, Tosca-Segura R, Arnedo-Pena A, Puig-Barberá J, Bellido-Blasco JB, Pac-Sa MR, et al. Incidence of allergic rhinitis in a cohort of schoolchildren between 1994 and 2002 in Castellón (Spain), following the ISAAC study. An Pediatr. 2007;66:154-8.

7. López-Silvarrey Varela A, González Barcala FJ, Paz Esquete JJ, Pérez Castro TR, Valdés Cuadrado L, Castro Iglesias A. Prevalencia de síntomas de asma y rinitis en la población de Coruña. An Pediatr. 2007;66:146-53.

8. Sánchez-Lerma B, Morales-Chirivella FJ, Peñuelas I, Blanco Guerra C, Mesa Lugo F, Aguinaga-Ontoso I, et al. High prevalence of asthma and allergic diseases in children aged 6 and 7 years from the Canary Islands: The International Study of Asthma and Allergies in Childhood. J Invest Allergol Clin Immunol. 2009;19:383-90.

9. Morais-Almeida M, Nunes C, Garpar A, Falcão H, Ferreira M, TodoBom A, et al. Rinite em idade pré-escolar: prevalência e caracterização. Estudo ARPA Kids. Rev Port Imunoalergol. 2007;15:387-410.

10. Beugre JB, Beugre-Kouassi AM, Bileya AM, Sonan NK, Adjoua $R$, Bamba $M$, et al. Prevalence of rhino-pharyngeal disease in the presence of malocclusion in school children in the village of Abidjan. Odontostomatol Trop. 2005; 28:27-35.

11. Moss ML. The primary role of functional matrix in facial growth. Am J Orthod. 1969;55:566-77.

12. Smith RM, Gonzalez C. The relationship between nasal obstruction and craniofacial growth. Pediatr Clin North Am. 1989;36:1423-34.

13. McNamara JA. Influence of respiratory pattern on craniofacial growth. Angle Orthod. 1981;51:269-300.

14. Harvold EP, Tomer K. Primate experiments on mandibular growth direction. Am J Orthod. 1982;82:114-9.

15. Harvold EP, Tomer BS, Vargervik K, Chierici G. Primate experiments on oral respiration. Am J Orthod. 1981;79:359-72.

16. Motta J, Martins MD, Fernandes KP, Mesquita Ferrari A, BiasottoGonzalez DA, Bussadori SK. Relação da postura cervical e oclusão dentária em crianças respiradoras orais. Rev CEFAC. 2009;11:298-304.

17. Guyton AC, Hall JE. Tratado de Fisiologia Médica. $10^{\mathrm{a}}$ ed. Rio de Janeiro: Guanabara Koogan; 2006.

18. Marchesan IQ. Motricidade oral: visão clínica do trabalho fonoaudiológico integrado com outras especialidades. $2^{a}$ ed. São Paulo: Pancast; 1993.

19. McKeovan P, Mew J. Cranio-facial changes and mouth breathing. Iris Dentist. 2011, [Consultado 2015 Fev 14]. Disponível em: http://buteyko. ie/images/pdf/Irish_Dentist_Journal_article.pdf.

20. Enlow DH. Crescimento facial. São Paulo: Artes Médicas; 1993.

21. Cuccia AM, Lotti M, Cardonna D. Oral breathing and head posture. Angle Orthod. 2007;78:77-82.

22. Wenzel A, Höjensgaard E, Henriksen JM. Craniofacial morphology and head posture in children with asthma and perennial rhinitis. Eur $\mathrm{J}$ Orthod. 1985; $7: 83-92$
23. Fields HW, Warren DW, Black K, Phillips CL. Relationship between vertical dentofacial morphology and respiration in adolescents. Am J Orthod Dentofacial Orthop. 1991;99:147-54.

24. Stein E, Flax SJ. A cephalometric study of children with chronic perennial allergic rhinitis. J Dent Assoc S Afr. 1996;51:794-801.

25. Bresolin D, Shapiro PA, Shapiro GG, Chapko MK, Dassel S. Mouth breathing in allergic children: its relationship to dentofacial development. Am J Orthod. 1983;83:334-40.

26. Trask GM, Shapiro GG, Shapiro PA. The effects of perennial allergic rhinitis on dental and skeletal development: a comparison of sibling pairs. Am J Orthod Dentofacial Orthop. 1987;92:286-93.

27. Crupi P, Portelli M, Matarese G, Nucera R, Militi A, Mazza M, et al. Correlations between cephalic posture and facial type in patients suffering from breathing obstructive syndrome. Eur J Paediatr Dent 2007;8:77-82.

28. Freitas FN, Bastos EP, Primo LS, Freitas VL. Evaluation of the palate dimensions of patients with perennial allergic rhinitis. Int J Paediatr Dent. 2001;11:365-71.

29. Löfstrand-Tideström B, Thilander B, Ahlqvist-Rastad, Jakobsson $O$ Hultcrantz E. Breathing obstruction in relation to craniofacial and dental arch morphology in 4 year-old children. Eur J Orthod. 1999;21:323-32.

30. Souki BQ, Pimenta GB, Souki MQ, Franco LP, Becker HM, Pinto JA. Prevalence of malocclusion among mouth breathing children: Do expectations meet reality? Int J Pediatr Otorhinolaryngol. 2009;73:76773.

31. Woodside DG, Linder-Aronson S, Stubbs DO. Relationship between mandibular incisor crowding and nasal mucosal swelling. Proc Finn Dent Soc. 1991;87:127-38.

32. Dunn GF, Gren LJ, Cunat JJ. Relationships between variation of mandibular morphology and variation of nasopharyngeal airway size in monozygotic twins. Angle Orthod. 1973;43:129-35

33. Krasny M, Wysocki J, Zadurska M, Skarzynski PH. Relative nasopharyngeal patency index as possible objective indication for adenoidectomy in children with orthodontic problems. Int $\mathrm{J}$ Ped Otorhinolariyngol. 2011;75:250-5

34. Ceylan I, Oktay H. A study on the pharyngeal size in different skeletal patterns. Am J Orthod Dentofacial Orthop. 1995;108:69-75.

35. Freitas MR, Alcazar NM, Janson G, Freitas KM, Henriques JF. Upper and lower pharyngeal airways in subjects with class I and class II malocclusions and different growth patterns. Am J Orthod Dentofacial Orthop. 2006;130:742-5

36. Cheng MC, Enlow DH, Papsidero M, Broadbent BH Jr, Oyen O, Sabat $M$. Developmental effects of impaired breathing in the face of growing child. Angle Orthod. 1988;58:309-20.

37. Tourne LP. The long face syndrome and impairment of the nasopharyngeal airway. Angle Orthod. 1990;60:167-76.

38. Juliano ML, Machado MA, Carvalho LB, Zancanella E, Santos GM, do Prado LB, et al. Polysomnographic findings are associated with cephalometric measurements in mouth-breathing children. J Clin Sleep Med. 2009;5:554-61.

39. Drevensek M, Papic JS. The influence of the respiration disturbances on the growth and development of the orofacial complex. Coll Antropol. 2005;29:221-5.

40. Harari D, Redlich M, Miri S, Hamud T, Gross M. The effect of mouth breathing versus nasal breathing on dentofacial and craniofacial development in orthodontic patients. Laryngoscope. 2010;120:2089-93

41. Zicari AM, Duse M, Occasi F, Luzzi V, Ortolani E, Bardanzellu F, et al. Cephalometric pattern and nasal patency in children with primary snoring: the evidence of a direct correlation. PLoS One. 2014;9:e111675 
Helena Afonso AGOSTINHO, Ivo Álvares FURTADO, Francisco Salvado e SILVA, Josep USTRELL TORRENT

\section{Cephalometric Evaluation of Children with Allergic Rhinitis and Mouth Breathing}

Acta Med Port 2015:28:316-321

Publicado pela Acta Médica Portuguesa, a Revista Científica da Ordem dos Médicos

Av. Almirante Gago Coutinho, 151

1749-084 Lisboa, Portugal.

Tel: +351218428 215

E-mail: submissao@actamedicaportuguesa.com

www.actamedicaportuguesa.com

ISSN:0870-399X | e-ISSN: 1646-0758

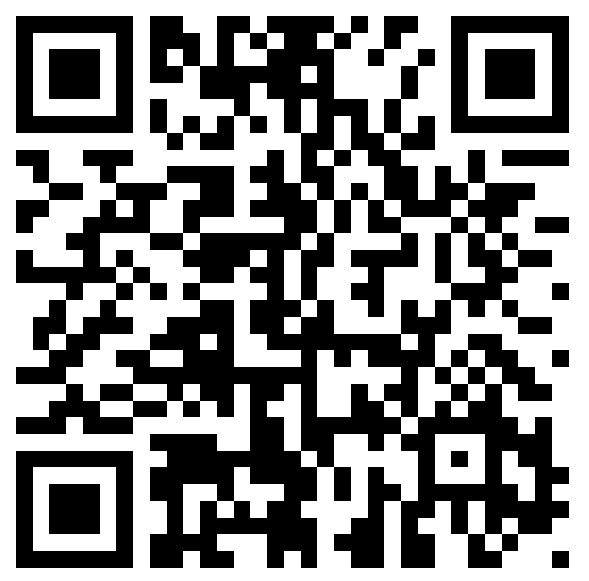

